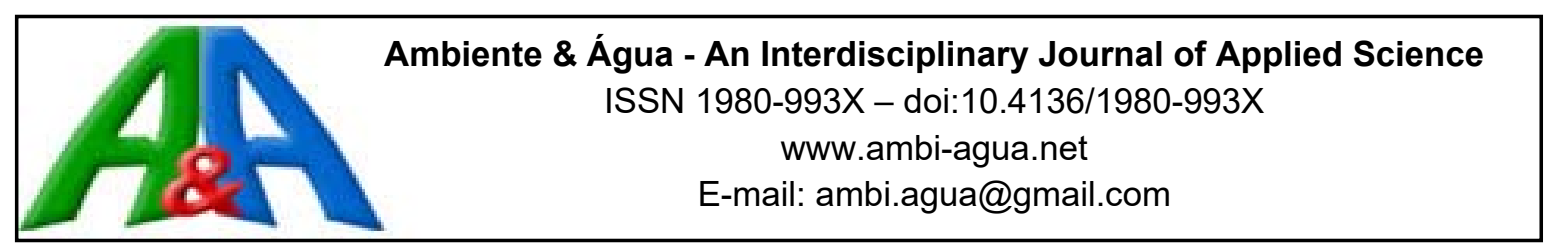

\title{
Effects of global climate change on chlorophyll-a concentrations in a tropical aquatic system during a cyanobacterial bloom: a microcosm study
}

doi:10.4136/ambi-agua.2014

Received: 11 Oct. 2016; Accepted: 23 Feb. 2017

\author{
Meirielle Euripa Pádua de Moura ${ }^{1}$; Lorraine dos Santos Rocha ${ }^{2}$; \\ João Carlos Nabout ${ }^{2 *}$ \\ Universidade Estadual de Goiás (UEG), Anápolis, GO, Brasil \\ ${ }^{1}$ Departamento de Recursos Naturais do Cerrado \\ ${ }^{2}$ Departamento de Ciências Biológicas \\ *Autor correspondente: e-mail: joao.nabout@ueg.br, \\ meirielle-euripa@hotmail.com, santoslor18@gmail.com
}

\begin{abstract}
Recent studies have investigated the impact of climate change on aquatic environments, and Chlorophyll- $a$ (Chl- $a$ ) concentration is a quick and reliable variable for monitoring such changes. This study evaluated the impact of rainfall frequency as a diluting agent and the effect of increased temperature on Chl- $a$ concentrations in eutrophic environments during a bloom of cyanobacteria. This was based on the hypothesis that the concentration of Chl- $a$ will be higher in treatments in which the rainfall frequency is not homogeneous and that warmer temperatures predicted due to climate change should favor higher concentrations of Chl-a. The experiment was designed to investigate three factors: temperature, precipitation and time. Temperature was tested with two treatment levels $\left(22^{\circ} \mathrm{C}\right.$ and the future temperature of $\left.25^{\circ} \mathrm{C}\right)$. Precipitation was tested with four treatments (no precipitation, a homogeneous precipitation pattern, and two types of concentrated precipitation patterns). Experiments were run for 15 days, and Chl- $a$ concentration was measured every five days in each of the temperature and precipitation treatments. The water used in the microcosms was collected from a eutrophic lake located in Central Brazil during a bloom of filamentous cyanobacteria (Geilterinema amphibium). Chl-a levels were high in all treatments. The higher temperature treatment showed increased Chl- $a$ concentration $(\mathrm{F}=10.343 ; P=0.002)$; however, the extreme precipitation events did not significantly influence Chl- $a$ concentrations $(\mathrm{F}=1.198 ; P=0.326)$. Therefore, the study demonstrates that future climatic conditions (projected to 2100), such as elevated temperatures, may affect the primary productivity of aquatic environments in tropical aquatic systems.
\end{abstract}

Keywords: extreme events, Geitlerinema amphibium, primary productivity, temperature.

\section{Efeito das mudanças climáticas globais na concentração de Chlorofila-a em um Sistema aquático tropical durante uma floração de cianobactéria: Um estudo em microcosmo}

\section{RESUMO}

Estudos recentes têm investigado o impacto das mudanças climáticas em ambientes aquáticos, além disso a Clorofila-a (Clo-a) é uma variável de rápida avaliação e confiável para 
o monitoramento de ambientes aquáticos. O objetivo do presente estudo foi avaliar o impacto da frequência da precipitação e do aumento da temperature na concentração de Clo-a em um ambiente aquático eutrófico durante um período de floração de cianobactéria. As hipóteses para o presente trabalho: i) A concentração de Clo-a será maior em tratamentos em que a frequencia de precipitação não é homogênea, e ii) Temperaturas mais quentes devem promover aumento na concentração de Clo-a. Foi utilizado um desenho experimental com três fatores: Precipitação, temperature e tempo. A temperature foi avaliada em dois tratamentos $\left(22^{\circ} \mathrm{C}\right.$ e a temperatura futura de $25^{\circ} \mathrm{C}$ ). A precipitação foi avaliada em quatro tratamentos (ausência de precipitação, precipitação homogênea, e dois tipos precipitação concentrada). O experimento foi desenvolvido por 15 dias e a concentração de Clo-a foi mensurada a cada cinco dias para cada tratamento. Os níveis de Clo-a foram elevados em todos tratamentos, além disso, a concentração de Clo-a foi maior em tratamentos mais aquecidos (simulando cenário futuro) $(\mathrm{F}=10.343 ; P=0.002)$; entretanto, os eventos extremos de precipitação não demonstraram influência na concentração de Clo-a $(\mathrm{F}=1.198 ; P=0.326)$. Portanto, o presente trabalho demonstrou que as condições climáticas futuras (projetadas para 2100), como o aumento da temperatura, devem afetar a produtividade primária de ambientes aquáticos.

Palavras-chaves: eventos extremos, Geitlerinema amphibium, produtividade primária, temperatura.

\section{INTRODUCTION}

The study of global climate change has attracted interest from the scientific community since the 1970s (e.g., Kopec, 1971). However, it was not until the beginning of the twenty-first century that scientific publications concerning climate change increased significantly (see Nabout et al., 2012a). Various scenarios have been proposed concerning the negative effects of climate change on human and natural systems, including warming and ocean acidification (Christensen et al., 2006; Doney et al., 2009), biodiversity loss (Hoegh-Guldberg et al., 2007), loss of arable land (Nabout et al., 2012b), and changes to disease vector distributions (Paz, 2015).

In aquatic environments, the major factors impacted by increased air temperatures are changes in precipitation and wind (Nickus et al., 2010; Roland et al., 2012). These factors can cause physical changes to the environment through stratification (Jeznach and Tobiason, 2015) or turbidity (Meerhoff et al., 2007), and chemical changes such as oxygen concentration (Gordon et al., 2004; Jeppesen et al., 2013) or nutrient cycling (Lecerf et al., 2007), and biological changes in the phenology of species (Daufresne et al., 2009). Experimental approaches have been used to evaluate the effect of climate change in aquatic environments. These experiments typically focus on the effects of the increased temperature expected in future scenarios (Jeppesen et al., 2010; Yvon-Durocher et al., 2010; Roland et al., 2012). However, recent studies have investigated other elements affecting aquatic ecosystems as well as their combined effects, such as the interaction between warming, drying, and acidification on consumers and planktonic producers (Christensen et al., 2006), the effects of climate change on water levels compounded with stratification (Berger et al., 2010), the effect of light and $\mathrm{CO}_{2}$ enrichment on nutrient concentrations (Andersen et al., 2005), and the effect of temperature and predation on phytoplankton community (He et al. 2015).

In addition to changes in temperature, the Intergovernmental Panel on Climate Change (IPCC, 2014) predicts that tropical ecosystems will experience altered hydrological cycles with an increased frequency of extreme events such as concentrated precipitation (IPCC, 2014). Extreme rainfall in some river basins can lead to increased flooding risk (Rockström et al., 2014), changes in runoff (Roland et al., 2012), and changes in Chl- $a$ concentrations (Belnap et al., 2005). Thus, extreme rainfall events can change dilutive effects and reduce zooplankton 
predation, promoting an increase in Chl- $a$ concentrations (see Dolan et al., 2000 for dilution effects). In addition to altered aquatic and peripheral communities, climate change can also compromise water resource quality (Codd, 2000; IPCC, 2014). Certain types of climate change can cause eutrophication that stimulates the growth of cyanobacteria facilitating the concentration of toxins (Reichwaldt and Ghadouani, 2012). Thus, studies that investigate the combined effect of climate change phenomena, such as elevated temperature and precipitation, are necessary in order to understand the changing conditions of tropical aquatic environments.

Experimental studies are therefore important tools to test the effects of climate change in aquatic ecosystem (see for example Li et al., 2016; 2017; Short et al., 2016). In fact, the majority of these experimental studies have been developed in temperate regions, and thus offer little insight about the impact of climate change in tropical aquatic ecosystems (see Roland et al., 2012). Nonetheless, experimental and whole lakes studies have shown that climate change (e.g. extreme events and warming) can affect aquatic tropical environments by modifying their geochemistry (Roland et al., 2012), altering species composition and functional groups (e.g. Costa et al., 2015), or increasing cyanobacterial dominance (Kosten et al., 2012). In fact, toxic Cyanophyceae has occurred in tropical environments (Mowe et al., 2015a).

Some studies have not found any relationship between temperature change and Chl- $a$ concentrations (see Moss et al., 2003; Feuchtmayr et al., 2009). Due to the diversity of phytoplankton species, there are many optimum temperature ranges for growth (Seip and Reynolds, 1995), thus elevated temperatures may not change the size of the community, but rather species composition (Moss et al., 2003 Van de Bund et al., 2004). Other studies, however, have found associations between increased temperature and frequency of cyanobacterial bloom phenomena (Reynolds, 2006; Jeppesen et al., 2009; Tundisi et al., 2015; Mowe et al., 2015b) and increased gross primary production (Yvon-Durocher et al., 2015).

This study evaluated the impact of rainfall frequency and increased temperature on chlorophyll- $a$ concentrations in eutrophic environments during a bloom of cyanobacteria. This was based on the expectations that: i) the intensity of rainfall in a short period of time would increase chlorophyll- $a$ concentrations in the treatments with the most homogeneous precipitation conditions, and ii) the warmer temperatures predicted due to climate change should favor higher concentrations of chlorophyll- $a$.

\section{MATERIAL AND METHODS}

\subsection{Experimental design}

The experimental design investigated three factors: temperature, precipitation, and time. There were two temperature levels (current and future) and four levels of precipitation (no precipitation, a homogeneous precipitation pattern, and two types of concentrated precipitation patterns). Experiments were run for 15 days, and Chl- $a$ concentration was measured every five days in each temperature and precipitation treatment.

Experiments were performed in microcosms. We prepared 40 beaker microcosms, each with a total volume of $2 \mathrm{~L}$. Each beaker received $1 \mathrm{~L}$ of water initially from an artificiallandscape with a eutrophic lake located at the Universidade Estadual de Goiás (City of Anápolis, Central Brazil). Samples were gathered from the lake during a bloom of the filamentous cyanobacteria, Geitlerinema amphibium (Figure 1 in supplementary material S1), in May 2015. Other organisms, such as other species of algae or zooplankton adhering to the mass of Geitlerinema amphibium were not removed. However, the analysis of algae species presented in this lake indicated that $99 \%$ of the total biomass was represented by G. amphibium. Thus, the Chl-a analysis used in this study was represented exclusively by this species.

Rev. Ambient. Água vol. 12 n. 3 Taubaté - May / Jun. 2017 


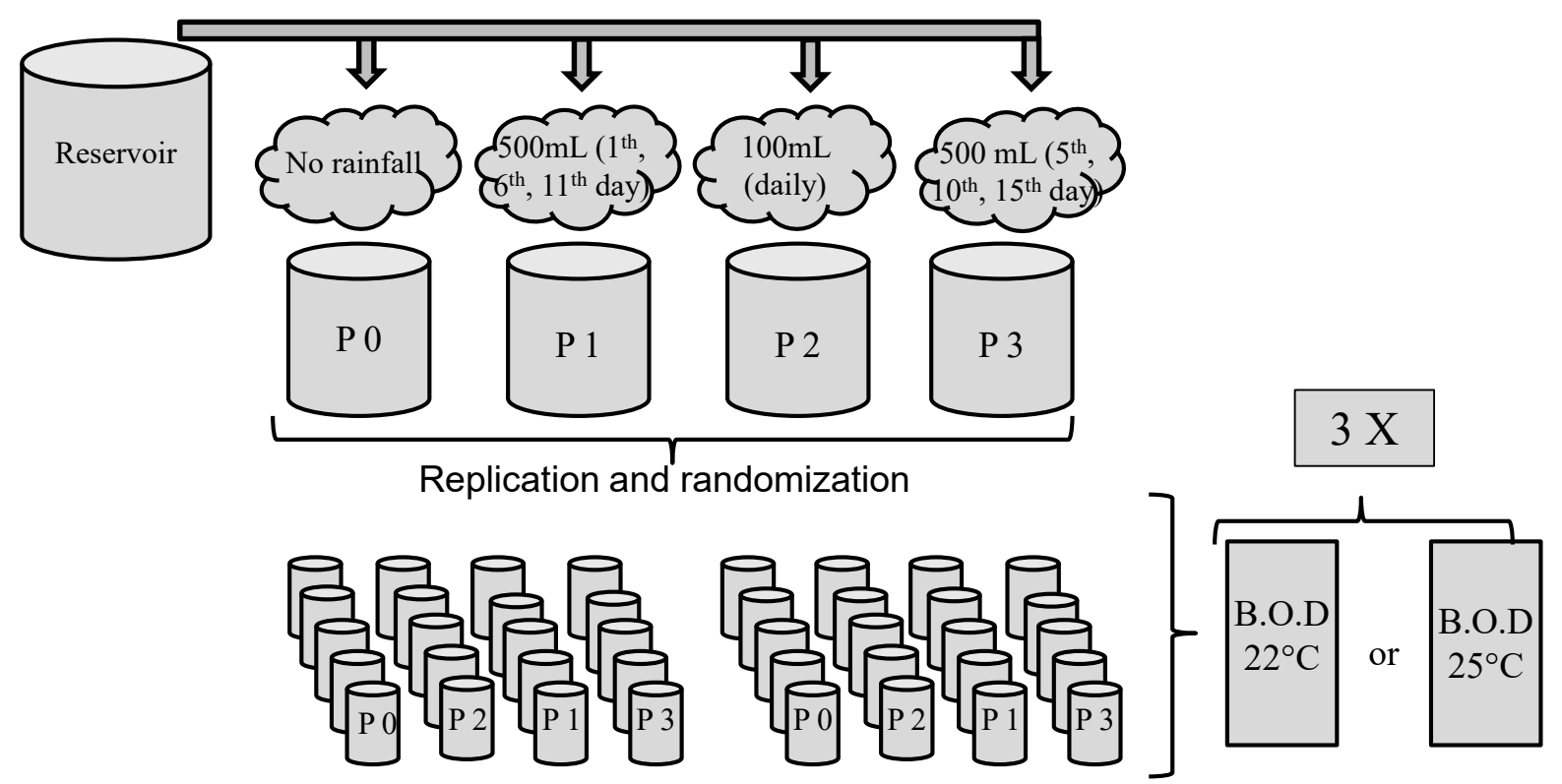

Figure 1. Schematic representation of the experiment. Water from a lake was used to fill the microcosms. The microcosm P0 received no distilled water, P1 received $500 \mathrm{~mL}$ of distilled water on the first day and every five days following, $\mathrm{P} 2$ received $100 \mathrm{~mL}$ of distilled water daily, and P3 received $500 \mathrm{~mL}$ of distilled water on the fifth day and every five days following. The experiments were placed in BOD incubators, simulating current $\left(22^{\circ} \mathrm{C}\right)$ and future $\left(25^{\circ} \mathrm{C}\right)$ temperatures. There were 20 replicates of each treatment of temperature and 10 replicates of each treatment of precipitation. The experiment was conducted for 15 days with samples collected every five days for Chlorophyll- $a$ measurements.

We obtained climate data from the EcoClimate database (Lima-Ribeiro et al., 2015) for neotropical regions, which includes current and predicted future climate conditions under different scenarios and global circulation models. We defined temperature and precipitation values using the CCSM model (Community Climate System Model) RCP 4.5 (obtained through the EcoClimate database; Lima-Ribeiro et al., 2015). The EcoClimate database has 19 climatic variables (derived from temperature and precipitation) for worldwide, containing current and future climate data. We used a climate scenario considered to have an intermediate level of greenhouse gas emissions, projected for the year 2100. This climate scenario has been used often in global climate change research (Pendergrass and Hartmann, 2012). The annual mean temperature for the Cerrado Biome is $23.7^{\circ} \mathrm{C}$, and the future climate scenarios estimate an increase of $3^{\circ} \mathrm{C}$ (according to the CCSM model, available in the EcoClimate database). According CCSM model the annual rainfall for the Cerrado Biome is $1170 \mathrm{~L}$ for the current climate scenario, and 1096L in future scenarios. Although this is only a small change in rainfall, the climate models suggest an increase of extreme events, such as, concentrated rainfall in a short period of time, and long periods of drought (see Marengo et al., 2009). Thus, based on this expectation, we simulated the concentrated precipitation as an extreme event. For this, the experiments received the same amount of water, but the variance was different. Thus, the concentrated treatments presented higher variance. The variance was estimated based on the change of precipitation in future scenarios, according to the CCSM model.

We used the temperature and precipitation values of the region where the lake samples were collected (City of Anápolis, Central Brazil), and selected two climatic variables: annual mean temperature and the precipitation of the wettest quarter corresponding to our study period. These two variables were obtained for the current and future climate scenarios. The current temperature was set at $22^{\circ} \mathrm{C}$ and the future temperature at $25^{\circ} \mathrm{C}$. For precipitation, we simulated three conditions of rainfall (two concentrated and one homogeneous) and one control, according 
to projected future scenarios (Marengo et al., 2009) Thus, for the same amount of precipitation we simulate extreme and homogeneous conditions.

Considering the climatic data of the study region, we developed the following experimental design. We simulated two temperature conditions in the microcosms; one treatment level corresponded to the current temperature of $22^{\circ} \mathrm{C}$ and the other corresponded to the future temperature of $25^{\circ} \mathrm{C}$ predicted according to CCSM RCP4.5, projected to 2100 . To simulate the effect of different rainfall patterns, distilled water was added to the microcosms. There were three precipitation scenarios, and a control ( $\mathrm{P} 0)$ with no precipitation. In the first treatment $(\mathrm{P} 1)$, $500 \mathrm{~mL}$ of distilled water was added to the microcosms every five days, beginning on the first day of the experiment, in order to simulate an extreme precipitation event. In the second treatment (P2), $100 \mathrm{~mL}$ of distilled water was added daily to the microcosms in order to simulate frequent rainfall. In the third treatment (P3), $500 \mathrm{~mL}$ of distilled water was added every five days beginning on the fifth day of the experiment. Treatments P1 and P3 simulated similar extreme events but with different start dates during the experiment (Figure 1).

We distributed the precipitation treatments in two BOD incubators with a photoperiod of $12 \mathrm{~h} / 12 \mathrm{~h}$ set at the two different temperatures, $22^{\circ} \mathrm{C}$ and $25^{\circ} \mathrm{C}$. The distribution of beakers in BOD incubators was determined randomly. Thus, each temperature treatment had 20 replicas, and each precipitation treatment had 10 replicas.

Before the experiment, we developed two series of pilot experiments, in which it was possible to determine the temporal interval of the experiment (degradation of chlorophyll-a occurred at more than 15 days), time among water adding, the method for adding water, time of light exposure, and other factors.

\subsection{Chlorophyll-a analysis}

The water from each microcosm was filtered through $47 \mathrm{~mm}$ glass fiber filters (Milipore $0.45 \mathrm{~m}$ ) prior to chlorophyll- $a$ analysis. Filters were placed in foil envelopes, stored in the dark, and kept in a refrigerator until processing. Quantitative analysis of chlorophyll- $a$ was performed after acetone extraction according to the method in Golterman et al. (1978). Chl- $a$ concentrations were determined once for each beaker using a volume of $190 \mathrm{~mL}$.

\subsection{Data analysis}

The difference between treatments was determined using a factorial analysis of variance (ANOVA, $\mathrm{P}<0.05$ ) for repeated measures (Zar, 2010). Chl- $a$ concentration was the dependent variable, with precipitation (at 3 levels) temperature (at 2 levels) and time as factors. Time was the total number of days in the experiment. The variables were $\log x+1$ transformed to meet the assumptions of normality and homogeneity of variances. To verify the assumptions, we used the Kolmogorov-Smirnov (KS) test for normality and the Levene homogeneity tests for homogeneity of variance.

\section{RESULTS AND DISCUSSION}

Chlorophyll- $a$ concentrations presented high values in all treatments (see descriptive statistic in Table 1); moreover, the value varied between treatments. Thus, after transforming the data, the assumption of normality required for ANOVA was supported, for Chl- $a$ on the $5^{\text {th }}$ day $(\mathrm{d}=0.18 ; \mathrm{P}=0.15), 10^{\text {th }}$ day $(\mathrm{d}=0.15 ; \mathrm{P}=0.20)$ and $15^{\text {th }}$ day $(\mathrm{d}=0.14 ; P=0.20)$. The assumption of homogeneity of variance was also supported for Chl- $a$ on the $5^{\text {th }}$ day $(\mathrm{F}=3.8$; $\mathrm{P}=0.06), 10^{\text {th }}$ day $(\mathrm{F}=1.1 ; \mathrm{P}=0.29)$ and $15^{\text {th }}$ day $(\mathrm{F}=0.07 ; \mathrm{P}=0.79)$. 
Table 1. Mean and standard deviation (SD) of Chlorophyll-a concentration $\left(\mu \mathrm{gL}^{-1}\right)$ registered in each treatment and levels in microcosm experiment.

\begin{tabular}{|c|c|c|c|c|c|c|c|}
\hline \multirow[t]{2}{*}{ Treatment } & \multirow[t]{2}{*}{ Levels } & \multicolumn{2}{|c|}{5 th day } & \multicolumn{2}{|c|}{ 10th day } & \multicolumn{2}{|c|}{15 th day } \\
\hline & & Mean & SD & Mean & SD & Mean & SD \\
\hline \multirow{3}{*}{ Temperature } & Current & 170.8 & 169.8 & 191.8 & 122.0 & 157.3 & 164.3 \\
\hline & Future & 179.9 & 117.6 & 223.1 & 161.2 & 706.5 & 1235.9 \\
\hline & $\mathrm{P} 1$ & 195.4 & 174.0 & 330.5 & 175.8 & 727.9 & 957.5 \\
\hline \multirow[t]{3}{*}{ Precipitation } & $\mathrm{P} 2$ & 152.5 & 48.2 & 144.0 & 86.3 & 235.8 & 308.8 \\
\hline & P3 & 240.4 & 213.4 & 178.9 & 70.7 & 624.4 & 1524.4 \\
\hline & P4 & 113.1 & 44.4 & 176.5 & 144.0 & 139.6 & 66.1 \\
\hline
\end{tabular}

Chl- $a$ concentrations varied significantly with temperature (Table 2; Figure 2). Increased temperature caused a significant increase in Chl- $a$ concentrations, but precipitation did not cause any significant difference in Chl- $a$ concentrations (Figure 3).

Table 2. Statistical significance of the treatment effects on Chlorophyll- $a$ concentration, considering the interaction of precipitation, temperature, and time, through repeated analysis of variance. Significant values are in bold $(P<0.05)$.

\begin{tabular}{lccc}
\hline & Degrees Freedom & $\mathrm{F}$ & $\mathrm{P}$ \\
\hline Temperature (Temp) & 1 & $\mathbf{1 0 . 3 4 3}$ & 0.002 \\
Precipitation (Prec) & 3 & 1.198 & 0.326 \\
Temp X Prec & 3 & 0.705 & 0.556 \\
Time & 2 & 0.241 & 0.786 \\
Time X Temp & 2 & $\mathbf{3 . 2 5 6}$ & 0.044 \\
Time X Prec & 6 & 0.634 & 0.702 \\
Time X Temp X Prec & 6 & 1.065 & 0.393 \\
\hline
\end{tabular}

The interaction between time and temperature was also significant. The third week of the experiment (15 days), there was an increase in the concentration of Chl- $a$ in treatments simulating future climate change scenarios (Figure 4). There was no significant interaction between time and precipitation. However, at elevated temperatures, time has an important role in determining concentrations of Chl- $a$.

We used experimentally manipulated microcosms to evaluate the effects of precipitation (i.e. rainfall) and temperature on the Chlorophyll- $a$ concentration of a sampled phytoplankton community collected from a eutrophic environment with an ongoing cyanobacterial bloom (G. amphibium). Although previous multi-factorial studies have investigated the impacts of climate change, this is the first study to assess the combined effects of temperature and precipitation in tropical environments. We found that temperature was the factor responsible for increased Chl- $a$ concentrations in future climate change scenarios. 


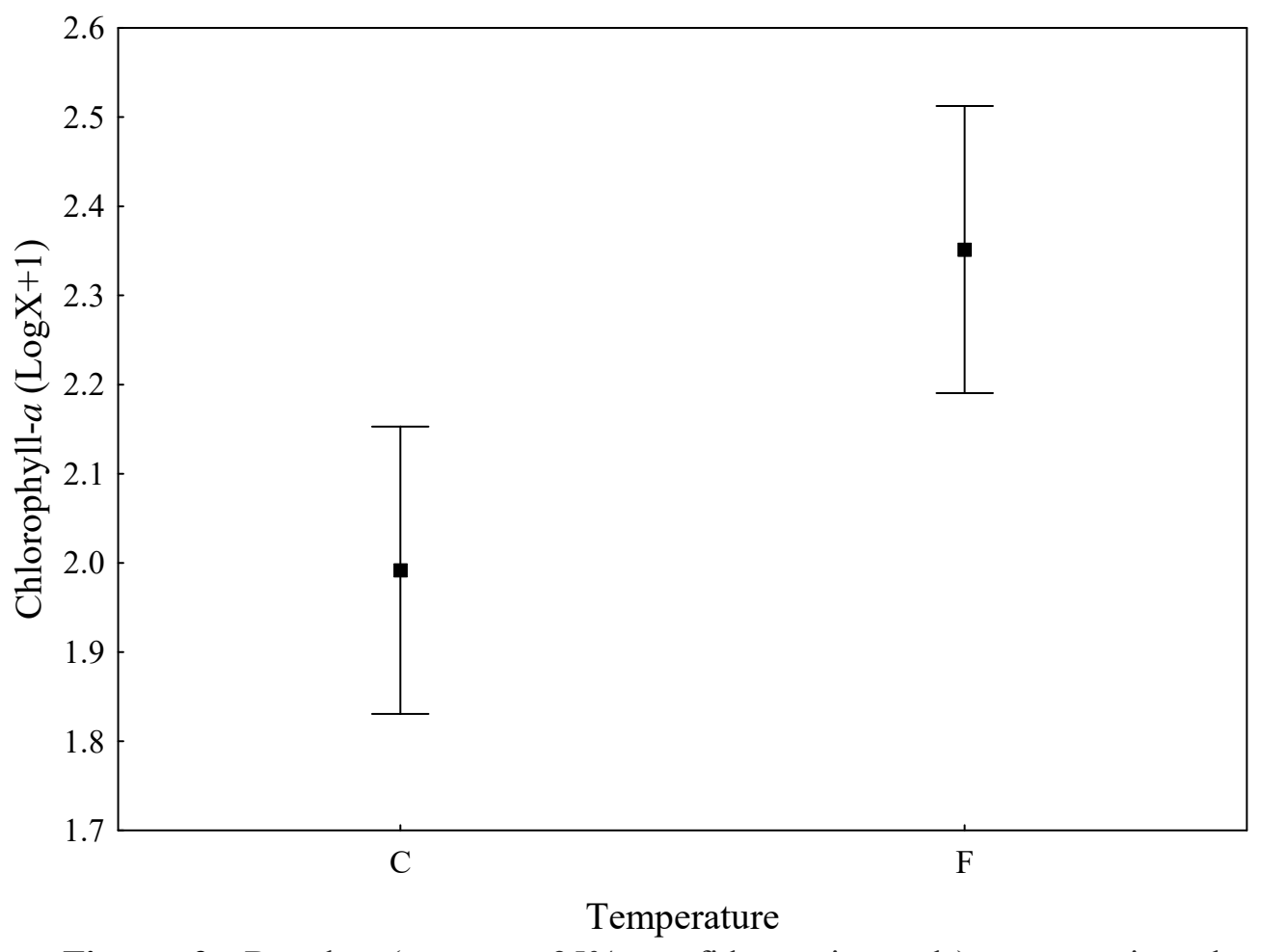

Figure 2. Boxplot (mean $\pm 95 \%$ confidence intervals) representing the concentration of Chlorophyll- $a$ in both simulated temperature conditions, where $\mathrm{C}$ is the current temperature and $\mathrm{F}$ the future temperature.

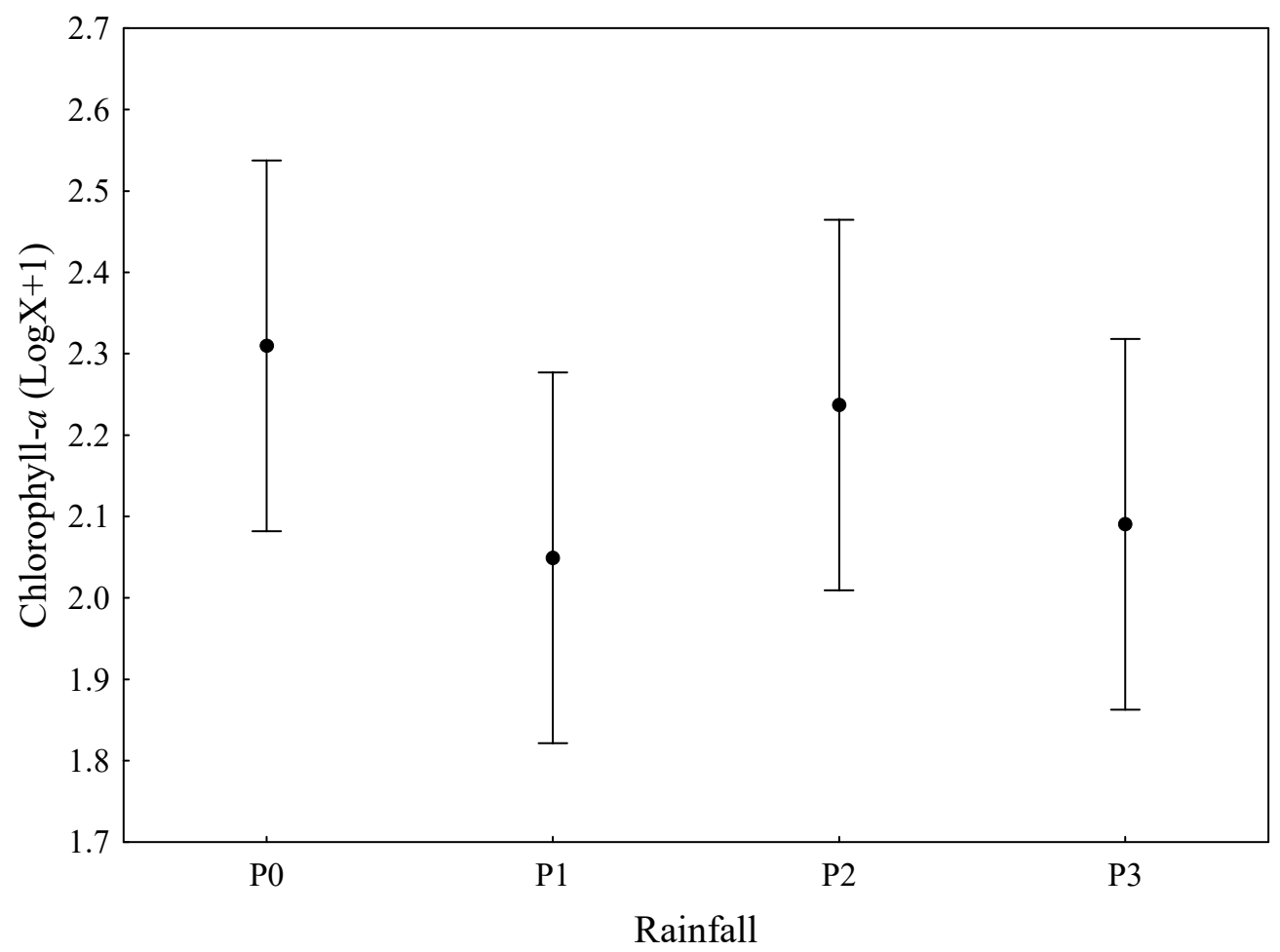

Figure 3. Boxplot (mean $\pm 95 \%$ confidence interval) representing the concentration of Chlorophyll- $a$ in the four simulated rainfall conditions (see details of $\mathrm{P} 0, \mathrm{P} 1, \mathrm{P} 2$, and $\mathrm{P} 3$ in methods). 


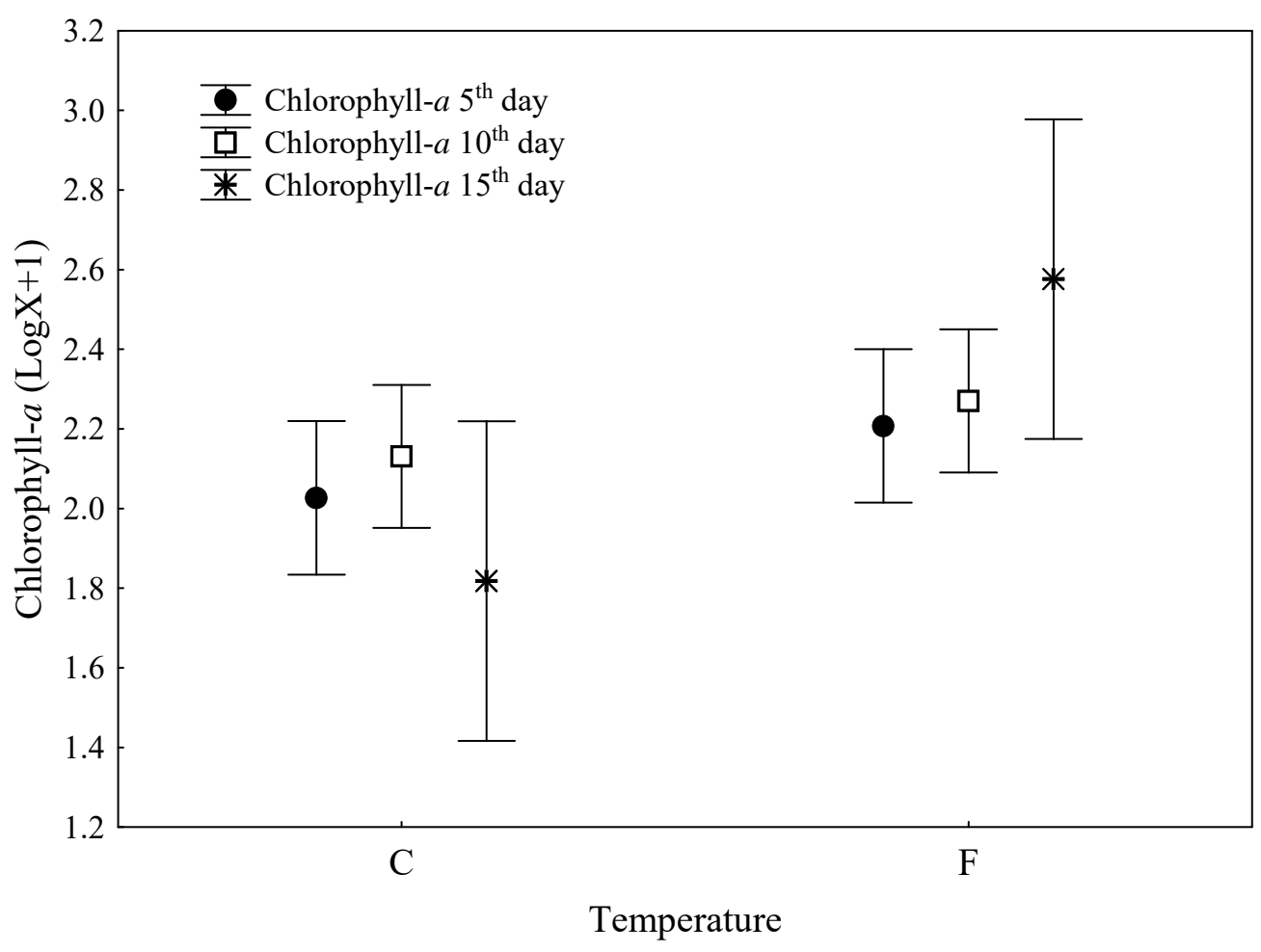

Figure 4. Boxplot (mean $\pm 95 \%$ confidence interval) representing the chlorophyll- $a$ concentration and the interaction effect among Temperature $(\mathrm{C}$ is current and $\mathrm{F}$ is Future) and time.

In fact, both thermal and hydrological changes can have serious consequences for aquatic ecosystems (Floury et al., 2012). Water temperature influences many processes in aquatic environments, including dissolved oxygen concentration (Gordon et al., 2004; Jeppesen et al., 2013), conductivity (Esteves et al., 2011), nutrient concentration (Jeppesen et al., 2009; 2011), and rates of primary productivity and decomposition (Lecerf et al., 2007).

Primary producers in aquatic environments are primarily controlled by nutrient availability, light (Huszar et al., 2006; Roland et al., 2012), and temperature (Roland et al., 2012). Temperature changes directly affect photosynthesis because higher temperatures accelerate the enzymatic reactions during photosynthesis and result in higher rates of primary productivity (Fernandes et al., 2005). Thus, algae growth tends to be linked with temperature, being faster at higher temperatures (Fernandes et al., 2005). Many cellular processes of algae depend on this variable (Reynolds, 1984). Moreover, many species of cyanobacteria are favored by an increase of temperature, promoting bloom events (see Moss et al., 2011; Jeppesen et al., $2013 ; 2014)$

An increase of water temperatures in the future may favor not only higher growth rates but may also increase the activity (Paerl and Huisman, 2009) and geographical distribution of cyanobacteria (Briand et al., 2004; Paerl and Huisman, 2009). Cyanobacterial blooms will likely be more frequent in future climatic conditions (Romo et al., 2005; Huber et al., 2012). This might be problematic because some species of cyanobacteria can produce toxic substances (Stewart et al., 2007; Paerl and Huisman, 2009) that can directly or indirectly contaminate other aquatic organisms through the food chain (Smith et al., 2008).

These blooms can also compromise the integrity of aquatic ecosystems by promoting massive oxygen consumption by algae and bacterial respiration during decomposition (Fernandes et al., 2005). In addition, cyanobacteria may be able to raise the local water 
temperature through light absorption, increasing their ability to dominate aquatic ecosystems (Paerl and Huisman, 2008).

In this study, precipitation does not affect the concentration of Chl- $a$; however, it was expected that concentrated rainfall can result in the dilution of nutrients and the washing away of algae blooms (Reichwaldt and Ghadouani, 2012) due to high discharge rates (Bouvy et al., 2003). In fact, the treatments (P1, P2, P3) presented higher Chl- $a$ concentrations than P0 (no precipitation) (see Figure 3). However, the possible nutrient dilution effect was compensated by the increase in temperature, promoting the growth of Chl- $a$ concentrations. Moreover, in microcosm the rainfall not remove the algae bloom (because of the physical limitations of the experiment); thus, even with the precipitation the original mass of the species was allowed to remain in the experiment, not being carried away. Finally, the addition of a large amount of water may interrupt the bloom and cause a lag in the resurgence of the algae bloom (Ahn et al., 2002), explaining the increase of Chl- $a$ in some treatments during the third week of the experiment.

However, it is still a challenge to provide precise answers regarding the consequences of climate change in aquatic ecosystems because there are a variety of Atmosphere-Ocean General Circulation Models (AOGCM), as well as climate scenarios (e.g. RCP 2.6, RCP 4.5, RCP6 and RCP 8.5). Current climate projections have a high degree of uncertainty, and this impedes the study of potential future impacts of warming. Microcosm experiments are one way to overcome this problem. This type of experiment provides important information about large-scale processes while only requiring minimal time to replicate different systems and scales (Benton et al., 2007). The use of microcosms in research is also supported by the need to tightly control conditions in order to correlate community dynamics with environmental variability. Future studies should consider the indirect effects of climate change, such as runoff, that are strongly influenced by the intensity of rain. Additionally, future studies investigating water temperature effects should also evaluate the uncertainty involved in choosing different climate change scenarios.

\section{CONCLUSIONS}

Based on our results, we reject our first hypothesis that extreme precipitation events increase Chl- $a$ concentrations relative to homogeneous rainfall. However, it is important to consider that in this study we evaluated the effect of precipitation on the dilution of the Chl- $a$. Our results supported our second hypothesis; higher temperatures favor higher Chl- $a$ concentrations. The future temperature used in this study (RCP 4.5) is based on intermediate greenhouse gas emissions, which would cause changes in the primary productivity of eutrophic environments.

This study also adds more information to a number of recent studies that investigate the impact of climate change on aquatic environments. In addition, the use of microcosm has proven to be satisfactory. Therefore, new studies using a similar approach may be undertaken, and different factors may be explored, such as new climatic scenarios and climatic variables.

\section{ACKNOWLEDGEMENTS}

We thank L.C.G Vieira and F.B. Teresa for suggestions on early versions of the experimental design and manuscript. We thank the two anonymous reviewers whose suggestions helped to improve the manuscript. We thank the CNPq (Process 473730/2013-8), CAPES (Process 2036/2013) and FAPEG (Process 201210267001071) for their financial support. Meirielle Euripa Pádua de Moura and Lorraine dos Santos Rocha thank Universidade

Rev. Ambient. Água vol. 12 n. 3 Taubaté - May / Jun. 2017 
Estadual de Goiás (UEG) and CNPq, respectively, for their scholarships. João Carlos Nabout thanks CNPq (Process 309700/2013-2) for the "Produtividade em Pesquisa" Scholarship.

\section{REFERENCES}

AHN, C. Y.; CHUNG, A. S.; OH, H. M. Rainfall, phycocyanin and N:P rations related to cyanobacterial blooms in a Korean large reservoir. Hydrobiologia, v. 474, n. 1-3), p. 117 124, 2002. http://dx.doi.org/10.1023/A:1016573225220

ANDERSEN, T.; PEDERSEN, O.; ANDERSEN, F. O. Nutrient concentration in a Littorella uniflora community at higher $\mathrm{CO}_{2}$ concentrations and reduced light intensities. Freshwater Biology, v. 50, p. 1178-1189, 2005. http://dx.doi.org/10.1111/j.13652427.2005.01390.x

BELNAP, J.; PHILLIPS, S. P.; MILLER, M. E. Response of desert biological soil crusts to alterations in precipitation frequency. Oecologia, v. 141, n.2, p. 306-316, 2005. http://dx.doi.org/10.1007/s00442-003-1438-6

BENTON, T. G.; SOLAN, M.; TRAVIS, J. J. J.; SAIT, S. M. Microcosm experiments can inform global ecological problems. Trends and Ecology \& Evolution, v. 22, n. 10, p. 516-521, 2007. http://dx.doi.org/10.1016/j.tree.2007.08.003

BERGER, S. A.; DIEHL, S.; STIBOR, H.; TROMMER, G E.; RUHENSTROTH, M. Water temperature and stratification depth independently shift cardinal events during plankton spring succession. Global Change Biology, v. 16, p. 1954-1965, 2010. http://dx.doi.org/10.1111/j.1365-2486.2009.02134.x

BOUVY, M.; NASCIMENTO, S. M.; MOLICA, R. J. R.; FERREIRA, A.; HUSZAR, V.; AZEVEDO, S. M. F. O. Limnological features in Tapacura reservoir (northeast Brazil) during a severe drought. Hydrobiologia, v. 493, n. 1-3, p. 115-130, 2003. http://dx.doi.org/10.1023/A:1025405817350

BRIAND, J. F.; LEBOULANGER, J. F.; HUMBERT, J. F.; BERNAND, C.; DUFOUR, P. Cylindrospermopsis raciborskii (Cyanobacteria) invasion at mid-latitudes: selection, wide physiological tolerance, or global warming? Journal of Phycology, v. 40 n. 2, p. 231-238, 2004. http://dx.doi.org/10.1111/j.1529-8817.2004.03118.x

CHRISTENSEN, M. R.; GRAHAM, M. D.; VINEBROOKE, R. D.; FINDLAY, D. L.; PATERSON, M. J. TURNER, M. A. Multiple anthropogenic stressors cause ecological surprises in boreal lakes. Global Change Biology, v. 12, p. 2316-2322, 2006. http://dx.doi.org/10.1111/j.1365-2486.2006.01257.x

CODD, G. A. Cyanobacterial toxins, the perception of water quality, and the prioritization of eutrophication control. Ecological Engineering, v. 16, p. 51-60, 2000. http://dx.doi.org/10.1016/S0925-8574(00)00089-6

COSTA, M. R. A.; ATTAYDE, J. L.; BECKER, V. Effects of water level reduction on the dynamics of phytoplankton functional groups in tropical semi-arid shallow lakes. Hydrobiologia, v. 778, n. 1, p. 75-89, 2015. http://dx.doi.org/10.1007/s10750-015-25936

DAUFRESNE, M.; LENGFELLNERA, K.; SOMMER, U. Global warming benefits the small in aquatic ecosystems. PNAS, v. 106, n. 31, p. 12788-12793, 2009. http://dx.doi.org/10.1073/pnas.0902080106 
DOLAN, J. R.; GALLEGOS, C. L.; MOIGIS, A. Dilution effects on microzooplankton in dilution grazing experiments. Marine Ecology Progress Series, v. 200, p. 127-139, 2000. http://dx.doi.org/10.3354/meps200127

DONEY, S. C.; FABRY, V. J.; FEELY, R. A. KLEYPAS, J. A. Ocean acidification: the other CO2 problem. Annual Review of Marine Science, v. 1, p. 169-192, 2009. http://dx.doi.org/10.1146/annurev.marine.010908.163834

ESTEVES, F. A.; FIGUEREDO-BARROS, M. P.; PETRUCIO, M. M. Principais Cátions e Ânions. In: ESTEVES, F. A. (Ed.). Fundamentos de Limnologia. 3. ed. Rio de Janeiro: Interciências, 2011. p. 299-319.

FERNANDES, L. F.; LAGOS, P. D.; WOSIACK, A. C.; PACHECO, C. V.; DOMINGUES, L.; ZENDER-ALVES, L. Comunidades fitoplanctônicas em ambientes lênticos. In: ANDREOLI, C. V.; CARNEIRO, C. (Eds.). Gestão integrada de mananciais de abastecimento eutrofizados. Curitiva: Finep, 2005.

FEUCHTMAYR, H.; MORAN, R.; HATTON, K.; CONNOR, L.; HEYES, T.; MOSS, B.; Harvey, I. et al. Global warming and eutrophication: effects on water chemistry and autotrophic communities in experimental hypertrophic shallow lake mesocosms. Journal of Applied Ecology, v. 46, p. 713-723, 2009. http://dx.doi.org/10.1111/j.13652664.2009.01644.x

FLOURY, M.; DELATTRE, C.; ORMEROD, S. J. SOUCHON, Y. Global versus local change effects on a large European river. Science of Total Environment, v. 441, p. 220-229, 2012. http://dx.doi.org/10.1016/j.scitotenv.2012.09.051

GOLTERMAN, H. L.; CLYMO, R. S.; OHMSTAD, M. A. M. Methods for physical and chemical analysis of freshwaters. Oxford: Blackwell Scientific Publication, 1978. 214 p.

GORDON, N. D.; FINLAYSON, B. L.; MCMAHON, T. A. Stream Hydrology an introduction for ecologists. 2. ed. London: John Wily \& Sons, 2004. 423p.

HE, H.; ZHU, X.; SONG, X.; JEPPESEN, E.; LIU, Z. Phytoplankton response to winter warming modified by large-bodied zooplankton: an experimental microcosm study. Journal of Limnology, v. 74, n. 3, p. 618-622, 2015. http://dx.doi.org/10.4 081/jlimnol.2015.1066

HOEGH-GUldBERG, O.; MUMBY, P. J.; HOOTEN, A. J.; STENECK, R. S.; GREENFIELD, P.; GOMEZ, E. et al. Coral reefs under rapid climate change and ocean acidification. Science, v. 318, p. 1737-1742, 2007. http://dx.doi.org/10.1 126/science. 1152509

HUBER, V.; WAGNER, C.; GERTEN, D.; ADRIAN, R. To bloom or not to bloom: contrasting responses of cyanobacteria to recent heat waves explained by critical thresholds of abiotic drivers. Oecologia, v. 169, p 245-256, 2012. http://dx.doi.org/10.1007/s00442-011-21867

HUSZAR, V. L. M.; CARACO, N. F.; ROLAND, F.; COLE, J. Nutrient-chlorophyll relationships in tropical-subtropical lakes: do temperate models fit? Biogeochemistry, $v$. 79, p. 239-250, 2006. http://dx.doi.org/10.1007/978-1-4020-5517-1_11 
INTERGOVERNMENTAL PAINEL ON CLIMATE CHANGE. Climate change: synthesis report. 2014 Available in: http://ar5-syr.ipcc.ch/topic_futurechanges.php. Access in: July 2015.

JEPPESEN, E.; KRONVANG, B.; JØRGENSEN, T. B.; LARSEN, S. E. ANDERSEN, H. E.; SØNDERGAARD, M. et al. Recent climate-induced changes in freshwaters in Denmark. In: GOLDMAN, C. R.; KUMAGAI, M.; ROBARTS, R. D. (Eds.). Climatic change and global warming of Inland waters: impacts and mitigation for ecosystems and societies. [S.1.]: John Wiley \& Sons, 2013. p. 155-171.

JEPPESEN, E.; KRONVANG, B.; MEERHOFF, M.; SØNDERGAARD, M.; HANSEN, K. M.; ANDERSEN, H. E. et al. Climate change effects on runoff, catchment phosphorus loading and lake ecological state, and potential adaptations. Journal of Environmental Quality, v. 38, p. 1930-1941, 2009. http://dx.doi.org/10.2134/jeq2008.0113

JEPPESEN, E.; KRONVANG, B.; OLESEN, J. E.; AUDET, J.; SØNDERGAARD, M.; HOFFMANN, C. C. et al. Climate change effect on nitrogen loading from catchment in Europe: implications for nitrogen retention and ecological state of lakes and adaptations. Hydrobiologia, v. 663, p. 1-21, 2011. http://dx.doi.org/10.1007/s10750-010-0547-6

JEPPESEN, E.; MEERHOFF, M.; DAVIDSON, T. A.; TROLLE, D.; SONDERGAARD, M.; LAURIDSEN, T. I. et al. Climate change impacts on lakes: an integrated ecological perspective based on multi-faced approach, with special focus on shallow lakes. Journal of Limnology, v. 73, p. 88-111, 2014. http://dx.doi.org/10.4081/jlimnol.2014.844

JEPPESEN, E.; MOSS, B.; BENNION, H.; CARVALHO, L.; DE MEESTER, L. et al. Interaction of climate change and eutrophication. In: KERNAN, M.; BATTARBEE, R.; MOSS, B. (Eds.). Climate change impacts on freshwater ecosystems. Oxford: WileyBlackwell, 2010. p. 119-151.

JEZNACH, L. C.; TOBIASON, J. E. Future climate effects on thermal stratification in the Wachusett Reservoir. Journal AWWA, v. 107, n. 4, p. E197-E209, 2015. http://dx.doi.org/10.5942/jawwa.2015.107.0039

KOPEC, R. J. Global climate change and impact of a maximum sea level on coastal settlement. Journal of Geography, v. 70, p. 541-550, 1971. http://dx.doi.org/10.1 080/00221347108981908

KOSTEN, S.; HUSZAR, V. L.; BÉCARES, E.; COSTA, L. S.; DONK, E.; HANSSON, L. A. et al. Warmer climates boost cyanobacterial dominance in shallow lakes. Global Change Biology, v. 18, n. 1, p. 118-126, 2012. http://dx.doi.org/10.1111/j.1365-2486. 2011.02488.x

LECERF, A.; RISNOVEANU, G.; POPESCU, C.; GESSNER, M. O.; CHAUVET, E. Decomposition of diverse litter mixtures in streams. Ecology, v. 88, p. 219-227, 2007. http://dx.doi.org/10.1890/0012-9658(2007)88[219:DODLMI]2.0.CO;2

LI, Z.; HE, L.; ZHANG, H.; URRUTIA-CORDERO, P.; EKVALL, M. K.; HOLLANDER, J.; et al. Climate warming and heat waves affect reproductive strategies and interactions between submerged macrophytes. Global change biology, v. 23, n. 1, p. 108-116, 2017. http://dx.doi.org/10.1111/gcb.13405 
LI, W.; XU, X.; FUJIBAYASHI, M.; NIU, Q.; TANAKA, N.; NISHIMURA, O. Response of microalgae to elevated $\mathrm{CO}_{2}$ and temperature: impact of climate change on freshwater ecosystems. Environmental Science and Pollution Research, v. 23, n. 19, p. 1984719860, 2016. http://dx.doi.org/10.1007/s11356-016-7180-5

LIMA-RIBEIRO, M. S.; VARELA, S.; GONZÁLEZ-HERNÁNDEZ, J.; OLIVEIRA, G.; DINIZ-FILHO, J. A. F.; TERRIBILE, L. C. EcoClimate: a database of climate data from multiple models for past, present, and future for Macro ecologists and Biogeographers. Biodiversity Informatics, v. 10, p. 1-21, 2015. https://doi.org/10.17161/bi.v10i0.4955

MARENGO, J. A.; JONES, R.; ALVES, L. M.; VALVERDE, M. C. Future change of temperature and precipitation extremes in South America as derived from the PRECIS regional climate modeling system. International Journal of Climatology, v. 29, n. 15, p. 2241-2255, 2009. http://dx.doi.org/10.1002/joc.1863

MEERHOFF, M.; CLEMENTE, J. M.; MELLO, F. T.; IGLESIAS, C.; PEDERSEN, A. R.; JEPPESEN, E. Can warm climate-related structure of littoral predator assemblies weaken the clear water state in shallow lakes? Global Change Biology, v. 13, p. 1888-1897, 2007. http://dx.doi.org/10.1111/j.1365-2486.2007.01408.x

MOSS, B.; KOSTEN, S.; MEERHOFF, M.; BATTARBEE, R. W.; JEPPESEN, E.; MAZZEO, N. et al. Allied attack: climate change and eutrophication. Inland waters, v. 1, n. 2, p. 101-105, 2011.

MOSS, B.; MCKEE, D.; ATKINSON, D.; COLLINGS, S. E.; EATON, J. W.; GILL, A. B. et al. How important is climate? Effects of warming, nutrient addition and fish on phytoplankton in shallow lake microcosms. Journal of Applied Ecology, v. 40, p. 782 792, 2003. http://dx.doi.org/10.1046/j.1365-2664.2003.00839.x

MOWE, M. A.; MITROVIC, S. M.; LIM, R. P.; FUREY, A.; YEO, D. C. Tropical cyanobacterial blooms: a review of prevalence, problem taxa, toxins and influencing environmental factors. Journal of Limnology, v. 74, n. 2, p. 205-224, 2015a. http://dx.doi.org/10.4081/jlimnol.2014.1005

MOWE, M. A.; POROJAN, C.; ABBAS, F.; MITROVIC, S. M.; LIM, R. P.; FUREY, A. Rising temperatures may increase growth rates and microcystin production in tropical Microcystis species. Harmful Algae, v. 50, p. 88-98, 2015 b. http://dx.doi.org/10.1016/j.hal.2015.10.011

NABOUT, J. C.; CARVALHO, P.; PRADO, U. M.; BORGES, P. P.; MACHADO, K. B.; HADDAD, K. B. et al. Trends and biases in global climate change literature. Natureza \& Conservação, v. 10, p. 45-51, 2012 a.

NABOUT, J. C.; CAETANO, J. M.; FERREIRA, R. B.; TEIXEIRA, I. R.; ALVES, S. M. F. Using correlative, mechanistic and hybrid niche models to predict the productivity and impact of global climate change on maize crop in Brazil. Natureza \& Conservação, v. 10, p. $177-183,2012$ b.

NICKUS, U.; BISHOP, K.; ERLANDSSON, M.; EVANS, C. D.; FORSIUS, M.; LAUDON, H. et al. Direct impacts of climate change on freshwater ecosystems. In: KERNAN, M.; BATTARBEE, R. W.; MOSS, B. (Ed.). Climate change impacts on freshwater ecosystems. India: Wiley-Blackwell, 2010. 
PAERL, H.W.; HUISMAN, J. Blooms like it hot. Science, v. 320, p. 57-58, 2008. http://dx.doi.org/10.1111/j.1758-2229.2008.00004.x

PAERL, H.W.; HUISMAN, J. Climate Change: a catalyst for global expansion of harmful cyanobacterial blooms. Environmental Microbiology Report, v. 1, p. 27-37, 2009. http://dx.doi.org/10.1111/j.1758-2229.2008.00004.x

PAZ, S. Climate change impacts on West Nile virus transmission in a global context. Philosophical Transactions of the Royal Society. B., v. 370, p. 1-11, 2015. http://dx.doi.org/10.1098/rstb.2013.0561

PENDERGRASS, A. G.; HARTMANN, D. L. Global-mean precipitation and black carbono in AR4 simulations. Geophysical Research Letters, v. 39, n. 1, 2012. http://dx.doi.org/10.1029/2011GL050067

REICHWALDT, E. S.; GHADOUANI, A. Effects of rainfall patterns on toxic cyanobacterial blooms in a changing climate: Between simplistic scenarios and complex dynamics. Water Research, v. 46, p. 1372-1393, 2012. http://dx.doi.org/10.1016/j.watres.2011.11.052

REYNOLDS, C. S. The ecology of freshwater phytoplankton. Cambridge: University Press, 1984.

ROCKSTRÖM, J.; BRASSEUR, G.; HOSKINS, B.; LUCHT, W.; SCHELLNHUBER, J.; KABAT, P. et al. Climate change: The necessary, the possible and the desirable Earth league climate statement on the implications for climate policy from the 5th IPCC assessment. Earth's Future, v. 2, p. 606-611, 2014.

http://dx.doi.org/10.1002/2014EF000280

ROLAND, F.; HUSZAR, V. L. M.; FARJALLA, V. F.; ENRICH-PRAST, A.; AMADO, A. M. et al. Climate change in Brazil: perspective on the biogeochemistry of inland waters. Brazilian Journal of Biology, v. 72, p. 709-722, 2012. http://dx.doi.org/10.1590/S151969842012000400009

ROMO, S.; VILLENA, M. J.; SAHUQUILLO, M.; SORIA, J. M.; GIMENEZ, M.; ALFONSO, $\mathrm{T}$. et al. Response of a shallow Mediterranean lake to nutrient diversion: does it follow similar patterns as in northern shallow lakes? Freshwater Biology, v. 50, p. 1706-17, 2005. http://dx.doi.org/10.1111/j.1365-2427.2005.01432.x

SEIP, K. L.; REYNOLDS, C. S. Phytoplankton functional attributes along trophic gradient and season. Limnology and Oceanography, v. 40, p. 589-597, 1995.

http://dx.doi.org/10.4319/lo.1995.40.3.0589

SHORT, F. T.; KOSTEN, S.; MORGAN, P. A.; MALONE, S.; MOORE, G. E. Impacts of climate change on submerged and emergent wetland plants. Aquatic Botany, v. 135, p. 3-17, 2016. http://dx.doi.org/10.1016/j.aquabot.2016.06.006

SMITH, J. L.; BOYER, G. L.; ZIMBA, P. V. A review of cyanobacterial odorous and bioactive metabolites: Impacts and management alternatives in aquaculture. Aquaculture, v. 280, p. 5-20, 2008. http://dx.doi.org/10.1016/j.aquaculture.2008.05.007

STEWART, I.; SEAWRIGHT, A. A.; SHAW, G. R. Cyanobacterial poisoning in livestock, wild mammals and birds -- an overview. In: HUDNELL, H. K. (Ed.). Cyanobacterial harmful algal blooms: state of the science and research needs. [S.1.]: Springer, 2007. 
TUNDISI, J. G.; MATSUMURA-TUNDISI, T.; TUNDISI, J. E. M.; BLANCO, F. P.; ABE, D. S.; CONTRI, C. L. et al. A bloom of cyanobacteria (Cylindrospermopsis raciborskii) in UHE Carlos Botelho (Lobo/Broa) reservoir: a consequence of global change? Brazilian Journal of Biolology, v. 75, n. 2, p. 507-508, 2015. http://dx.doi.org/10.1590/1519-6984.24914

VAN DE BUND, W. J.; ROMO, S.; VILLENA, M. J.; VALENTIN, M.; VAN DONK, E.; VICENTE, K. Responses of phytoplankton to fish predation and nutrient loading in shallow lakes: a pan-European mesocosm experiment. Freshwater Biology, v. 49, n. 12, p. 1608-1618, 2004. http://dx.doi.org/10.1111/j.1365-2427.2004.01307.x

YVON-DUROCHER, G.; ALLEN, A. P.; MONTOYA, J. M.; TRIMMER, M.; WOODWARD, G. The temperature dependence of carbon cycle in aquatic ecosystems. Avdances in Ecological Research, v. 43, p. 267-313, 2010. http://dx.doi.org/10.1016/B978-0-12-385005-8.00007-1

YVON-DUROCHER, G.; ALLEN, A.P.; CELLAMARE, M.; DOSSENA, M.; GASTON, K. J.; LEITAO, M. et al. Five years of experimental warming increases the biodiversity and productivity of phytoplankton. PLoS Biology, v. 13, n. 12, 2015. http://dx.doi.org/10.1371/journal.pbio.1002324

ZAR, J. H. Biostatistical Analysis. 5. ed. [S.1.]: Pearson, 2010. 